\title{
PELAKSANAAN PENANGANAN PENYIDIKAN TINDAK PIDANA PERSETUBUHAN DAN PENCABULAN TERHADAP ANAK DI POLSEK EMPAT ANGKAT CANDUNG*
}

\author{
Rahmat Fauzi \\ STIH Putri Maharaja Payakumbuh, \\ Guguak Randah Kenagarian Guguak Tabek Sarojo Kecamatan IV Koto Kabupaten Agam \\ e-mail: rahmatfauzi24oke@gmail.com
}

\begin{abstract}
The purpose of this study was to find out and analyze the implementation of a criminal investigation of sexual intercourse and sexual abuse of children in the Fourth Admission Police Station. The method used in this research is empirical juridical research. The results showed that the research on the crime of intercourse and sexual abuse of children carried out by the investigating authority was in accordance with the provisions of the legislation. Investigation of this case is in accordance with the existing rules of receiving reports, confiscating evidence, arresting, detaining filing and sending files to the Public Prosecutor (P21). Factors inhibiting irregularities in the process of criminal acts of sexual intercourse and sexual abuse of children are: human resources from the investigator, victims are still children, the suspect does not argue, has nothing to do with seeing directly and does not want to come to provide assistance Information and bordering forensic doctors. The way out by investigators in the process of sexual intercourse and sexual abuse of children is to increase existing investigators and those requested by investigating members to the police station, allocate and request assistance to assist these sexual acts of sexual intercourse and coitus with the Social Service Bukittinggi, replace a lot of information and opinions will not come, then called back after it was visited at home to be able to provide information, the suspect did not confess then the investigator made a case at the location, processing evidence and multiply giving reports to provide information and help the doctor Forensics, the investigator is still waiting for the results of the post mortem.
\end{abstract}

Keywords: Investigator; Sex; Obscenity; Children.

\section{Abstrak}

Tujuan Penelitian ini adalah Mengetahui dan menganalisis pelaksanaan penanganan penyidikan tindak Pidana persetubuhan dan pencabulan terhadap anak di Polsek Empat Angkat Candung. Metode Pendekatan masalah yang dipergunakan dalam penelitian ini adalah penelitian secara yuridis empiris. Hasil penelitian menunjukkan bahwa penangan penyidikan tindak pidana persetubuhan dan pencabulan terhadap anak yang dilakukan oleh aparat penyidik telah sesuai dengan ketentuan peraturan perundang-undangan. Penyidikan terhadap kasus ini sesuai dengan aturan yang ada yaitu menerima laporan, melakukan sita barang bukti, penangkapan, penahanan pemberkasan dan kirim berkas ke Jaksa Penuntut Umum (P21). Faktor penghambat penyidik dalam memproses perkara tindak pidana persetubuhan dan pencabulan Terhadap Anak yaitu: hambatan yang menyangkut segi sumber daya manusia dari penyidik, korban masih anak-anak, tersangka tidak mengaku, tidak ada nya saksi yang melihat secara langsung dan saksi tidak mau datang untuk memberikan keterangan dan berbatasan dokter forensik. Jalan keluar yang diambil penyidik dalam memproses perkara tindak pidana persetubuhan dan pencabulan terhadap anak adalah berusaha untuk mengoptimalkan penyidik yang ada dan mengajukan penambahan anggota penyidik ke Polres, mengalukan dan meminta bantuan untuk mendampingi korban pencabulan dan persetubuhan ini ke Dinas Sosial Bukittinggi, memperbanyak saksi untuk memberikan keterangan dan saksi tidak mau datang maka dilakukan pemanggilan ulang setelah itu didatangi ke rumah agar bisa memberikan keterangan, tersangka tidak mengaku maka penyidik melakukan gelar perkara di

\footnotetext{
* Naskah diterima: 1 September 2019, direvisi: 28 Agustus 2019, disetujui untuk terbit: 30 September 2019

Doi: $10.3376 /$ jch.v5i1.207
} 
lokasi, memproses barang bukti dan memperbanyak menghadirkan saksi untuk memberikan keterangan dan keterbatasan Dokter Forensik, maka penyidik tetap menunggu hasil visum.

Kata Kunci: Penyidik; Persetubuhan; Cabul; Anak.

PENDAHULUAN

Negara Indonesia adalah Negara yang menjunjung tinggi penegakan hukum dan Hak Asasi Manusia, hal ini dikarenakan hukum dan Hak Asasi Manusia saling berkaitan satu sama lainnya. Hukum merupakan wadah yang mengatur segala hal mengenai perlindungan terhadap Hak Asasi Manusia. Pada hakikatnya tujuan diciptakan hukum agar tercipta kerukunan dan perdamaian dalam pergaulan hidup masyarakat. Namun pada kenyataannya dalam masyarakat masih bermunculan berbagai tindak pidana. Ini menunjukkan bahwa tujuan hukum itu belum terwujud sepenuhnya. Masyarakat Indonesia saat ini berada pada situasi dan kondisi sebagai masyarakat transisi, yang mana situasi masyarakatnya beralih dari sistem pemerintahan yang otoriter ke demokrasi melalui proses yang disebut reformasi. (Agil Widiyas Sampurna, 2016) Pentingnya perlindungan hukum terhadap korban kejahatan secara memadai tidak hanya menjadi isu nasional, melainkan juga menjadi isu internasional. Oleh karena itu, masalah ini harus mendapat perhatian yang serius. (Aprilianda, 2017)

Tindak pidana pencabulan dalam lingkungan keluarga ini juga merupakan salah satu bentuk perilaku menyimpang. Hal ini merupakan tantangan bagi aparat penegak hukum dan masyarakat. Oleh sebab itu maka pelaku kejahatan ini sudah sepantasnya mendapat sanksi berupa hukuman yang setimpal dengan perbuatannya. (Fachri Bey, 2011)

Perbuatan pidana adalah perbuatan yang dilarang oleh suatu aturan hukum, larangan mana disertai dengan ancaman atau sanksi yang berupa pidana tertentu. Perbuatan pidana dapat pula dikatakan tindak pidana, yaitu perbuatan yang oleh suatu aturan hukum dilarang dan diancam, asal saja dalam pada itu diingat bahwa larangannya ditujukan pada perbuatan yaitu suatu keadaan atau suatu kejadian yang ditimbulkan oleh kelakuan orang yang menimbulkan kejadian itu. Kejadian tidak dapat dilarang jika yang menimbulkan bukan orang. (Moeljatno, 1993)

Indonesia sebagai Negara hukum bertujuan menciptakan adanya ketertiban, keamanan, ketentraman, keadilan bernegara. Masalah kejahatan kesusilaan dihubungkan dengan perilaku menyimpang (tingkah laku menyimpang ialah tingkahlaku yang tidak baik tidak bisa diterima oleh masyarakat umumnya, dan tidak bisa sesuai dengan norma yang ada) (Kartini Kartono, 1983).

Kasus kejahatan yang terjadi di Indonesia menjadi bahan pembicaraan baik di dalam negeri maupun di luar negeri. Terjadinya kejahatan kesusilaan tersebut bukan hanya merupakan gangguan terhadap keamanan, ketertiban, ketentraman masyarakat semata-mata tetapi juga merupakan biaya yang besar bagi masa depan korban 
Rahmat Fauzi: Pelaksanaan Penanganan Penyidikan Tindak Pidana Persetubuhan...

kejahatan kesusilaan. Kejahatan kesusilaan yang banyak korbannya adalah anak-anak.

Anak adalah masa depan bangsa karena itu adalah wajar jika anak-anak dipersiapkan untuk mengisi masa depan yang lebih baik dan menjanjikan. Dalam Konvensi Hak Anak (KHA), yang dimaksud dengan anak adalah setiap orang belum mencapai usia 18 tahun. (Putra, Sabardi, \& Parman, 2018) Anak merupakan generasi penerus cita-cita bangsa, oleh karena itu komitmen dan perlakuan yang memperhatikan perkembangan dan peranan anak sebagai generasi penerus bangsa merupakan suatu hal yang harus dipegang oleh pemerintah Anak yang belum matang secara mental dan fisik, kebutuhannya harus dicukupi, pendapatnya harus dihargai, diberikan pendidikan yang benar dan kondusif bagi pertumbuhan dan perkembangan pribadi dan kejiwaannya, agar dapat tumbuh dan berkembang menjadi anak yang dapat diharapkan sebagai penerus bangsa. (Gadis Arivia, 2005)

Problematika berkenaan dengan tindak pidana asusila terhadap anak timbul karena hukuman penjara yang diberikan kepada pelaku tidak membuat orang-orang takut melakukan hal tersebut, malah semakin banyak pelaku tindak pidana perkosaan dan pencabulan terhadap anak. (Wahyuningsih, 2016)

Salah satu perbuatan yang dilarang oleh hukum pidana adalah pencabulan. Kitab Undang-Undang Hukum Pidana $\begin{array}{llr}\text { (Selanjutnya } & \text { disebut } & \text { KUHP) } \\ \text { menggolongkan } & \text { tindak } & \text { pidana }\end{array}$ pencabulan ke dalam tindak pidana kesusilaan. KUHP belum mendefinisikan dengan jelas maksud dari pencabulan itu sendiri dan terkesan mencampuradukkan pengertiannya dengan perkosaan atau persetubuhan.

Pencabulan merupakan salah satu dari kejahatan seksual yang diakibatkan dari adanya perubahan yang terjadi dalam struktur masyarakat kita. Pencabulan adalah jenis kejahatan yang berdampak sangat buruk terutama pada korbannya, sebab pencabulan akan melanggar hak asasi manusia serta dapat merusak martabat kemanusiaan, khususnya terhadap jiwa, akal dan keturunan. Kasuskasus tindak pidana pencabulan saat ini marak terdengar terjadi di Indonesia. Korban dalam kejahatan ini seringkali adalah anak-anak.

Tindak pidana pencabulan adalah suatu tindak pidana yang bertentangan dan melanggar kesopanan dan kesusilaan seseorang mengenai dan yang berhubungan dengan alat kelamin atau bagian tubuh lainnya yang dapat merangsang nafsu seksual. Ada beberapa bentuk dan jenis istilah tentang pencabulan adalah (Kartini Kartono, 1985):

1. Exhibitionism seksual yaitu, sengaja memamerkan alat kelamin pada anak.

2. Voyeurism yaitu, orang dewasa mencium anak dengan bernafsu.

3. Fonding yaitu, mengelus/meraba alat kelamin seorang anak.

4. Fellatio yaitu, orang dewasa memaksa anak untuk melakukan kontak mulut. 
Lahirnya Undang-Undang No. 23 Tahun 2002 Tentang Perlindungan Anak pada tanggal 22 Oktober 2002 diharapkan sebagai katup pengaman untuk menjamin perlindungan hak asasi anak salah satunya adalah jaminan perlindungan dari ekploitasi seksual terhadap anak. Hal ini secara tegas termaktub dalam Pasal 1 Ayat (2) UUPA. (Bob Sadiwijaya, Marlina, Mahmud Mulyadi, 2013) Upaya perlindungan hukum kepada anak di bawah umur pada dasarnya telah diatur dalam Kitab Undang-Undang Hukum Pidana (KUHP), khususnya Pasal 287 KUHP yang mengatur:

(1) Barangsiapa bersetubuh dengan sorang wanita yang bukan istrinya, pada hal diketahuinya atau sepatutnya harus diduganya bahwa umur wanita itu belum lima belas tahun, atau kalau umumya tidak jelas, bahwa belum waktunya untuk dikawinkan, diancam dengan pidana penjara paling lama sembilan tahun.

(2) Penuntutan dilakukan hanya atas pengaduan, kecuali bila umur wanita itu belum sampai dua belas tahun atau bila ada salah satu hal seperti tersebut dalam Pasal 291 dan Pasal 294.

Pada perkembangan berikutnya pemerintah memberlakukan UndangUndang Nomor 23 Tahun 2002 yang diperbaharui dengan Undang-Undang Nomor 35 Tahun 2014 tentang Perlindungan Anak. Pasal 81 mengatur:

1. Setiap orang yang dengan sengaja melakukan kekerasan atau ancaman kekerasan memaksa anak melakukan persetubuhan dengannya atau dengan orang lain, dipidana dengan pidana penjara paling lama 15 (lima belas) tahun dan paling singkat 3 (tiga) tahun dan denda paling banyak Rp 300.000.000,00 (tiga ratus juta rupiah) dan paling sedikit Rp 60.000.000,00 (enam puluh juta rupiah)

2. Ketentuan pidana sebagaimana dimaksud dalam Ayat (1) berlaku pula bagi setiap orang yang dengan sengaja melakukan tipu muslihat, kebohongan, atau membujuk anak melakukan persetubuhan dengannya atau dengan orang lain.

Pasal 82 Undang-Undang Nomor 23 Tahun 2002 jo Undang-Undang Nomor 35 Tahun 2014 jo Undang-Undang Nomor 35 Tahun 2014 tentang Perlindungan Anak mengatur bahwa setiap orang yang dengan sengaja melakukan kekerasan atau ancaman kekerasan, memaksa, melakukan tipu muslihat, serangkaian kebohongan, atau membujuk anak untuk melakukan atau membiarkan dilakukan perbuatan cabul, dipidana dengan pidana penjara paling lama 15 (lima belas) tahun dan paling singkat 3 (tiga) tahun dan denda paling banyak Rp 300.000.000,00 (tiga ratus juta rupiah) dan paling sedikit $\mathrm{Rp}$ 60.000.000,00 (enam puluh juta rupiah).

Selain itu Undang-Undang Perlindungan Anak juga diperlukan untuk menegaskan adanya kewajiban bagi negara, pemerintah, masyarakat, keluarga, orang tua dan anak, mengingat:

1. Kewajiban memberikan perlindungan anak walaupun sudah disadari merupakan kewajiban bersama, namun perlu diberikan landasan hukum secara khusus di samping 
Rahmat Fauzi: Pelaksanaan Penanganan Penyidikan Tindak Pidana Persetubuhan...

yang sudah dicantumkan dalam pasalpasal UUD 1945 atau dalam berbagai Peraturan Perundang-Undangan yang lain, agar dapat menjamin pelaksanaannya secara komprehensif dan tepat penanganan serta sarana, yang harus dilakukan oleh negara, pemerintah, masyarakat, keluarga dan orang tua anak.

2. Perlu adanya keseimbangan antara perlindungan hak anak dan pemberian kewajiban bagi anak dalam kapasitas mendidik anak. Oleh karena itu, di samping dilindungi hak-haknya, agar tidak menjadi salah asuh, salah arah, maka perlu ditunjukkan juga kewajiban yang perlu dilaksanakan oleh anak.

Peranan penyidik dalam menanggulangi kejahatan pencabulan perlu dilakukan untuk pencegahan terhadap kasus pencabulan terhadap anak dibawah umur dengan memberikan perlindungan terhadap korban dan memberikan efek jera terhadap pelaku pencabulan anak dibawah umur. Kepolisian merupakan salah satu komponen sistem peradilan pidana yang menjadi ujung tombak dalam penanggulangan kejahatan. Peranan kepolisian kelihatan lebih besar bila dibandingkan dengan komponen lainnya. Institusi ini sangat menentukan keberhasilan sistem peradilan pidana secara keseluruhan. Untuk itu Kepolisian disebut sebagai The Gate Keeper of Fungsi Kepolisian (Pasal 2 UndangUndang Nomor 2 Tahun 2002 Tentang Kepolisian) Adalah salah satu fungsi pemerintahan negara di bidang: Criminal Justice.

1. Pemeliharaan keamanan dan ketertiban masyarakat,

2. Penegakan hukum,

3. Perlindungan, pengayoman, dan pelayanan kepada masyarakat.

Tujuan Kepolisian RI (Pasal 4 Undang-Undang Nomor 2 Tahun 2002 Kepolisian) adalah Mewujudkan keamanan dalam negeri yang meliputi:

1. Terpeliharanya keamanan dan ketertiban masyarakat,

2. Tertib dan tegaknya hukum,

3. Terselenggaranya perlindungan, pengayoman,

4. Pelayan kepada masyarakat,

5. Serta terbinanya ketenteraman masyarakat dengan menjunjung tinggi hak asasi manusia.

Melihat dan memperhatikan tahun ke tahun kasus pencabulan dan persetubuhan yang terjadi di Polsek Empat Angkat Candung semakin meningkat. Pada tahun 2015 kasus yang di laporkan ke Polsek 1 kasus. Pada tahun 2016 kasus yang di laborkan ke Polsek 2 kasus. Sedangkan Pada tahun 2017 kasus yang di laporkan ke Polsek 4 kasus.

Salah satu contoh kasus pencabulan dan persetubuhan yang korbannya anak (Petikan Putusan Perkara No. 110/Pid.Sus/2016/PN.Bkt tentang Perkara Pencabulan) yaitu Polsek Empat Angkat Candung menangkap B pada tanggal 17 Mei 2017. Tersangka membujuk anak dan melakukan percabulan dengan barang bukti 1 celana pendek warna merah, 1 pasang baju kaos lengan panjang warna kombinasi biru merah dan kuning merek Angry Spider Bird, 1 HP Android merk 
Samsung GT-C3303i dan Baju Batik lengan panjang kombinasi hitam biru serta celana coklat.

Perbuatan pelaku tersebut dapat menimbulkan trauma fisik dan psikis terhadap korban terutama yang berusia anak-anak sehingga bisa berpengaruh ada perkembangan diri korban ketika dewasa nanti. Aparat penegak hukum dibebani tugas khusus untuk mengungkap suatu tindak pidana pencabulan terhadap anak yang dalam penyidikan pelaku tidak mengakui perbuatan tersebut dan juga tidak ada saksi yang melihat perbuatan tersebut. Penyelidikan ini harus dilakukan oleh orang yang miliki kemampuan khusus dan memberikan pengetahuan tentang undang-undang yang mengatur tentang perlindungan anak.

Berdasarkan latar belakang pemikiran di atas, maka permasalahan yang akan diteliti dapat dirumuskan sebagai berikut: Bagaimanakah pelaksanaan penanganan penyidikan tindak Pidana persetubuhan dan pencabulan terhadap anak di Polsek Empat Angkat Candung? Apakah faktor penghambat penyidik dalam memproses perkara tindak pidana persetubuhan dan pencabulan terhadap anak di Polsek Empat Angkat Candung ? Bagaimana jalan keluar yang diambil penyidik dalam memproses perkara tindak pidana persetubuhan dan pencabulan terhadap anak di Polsek Empat Angkat Candung?

\section{METODE PENELITIAN}

Penelitian adalah suatu proses, yaitu suatu rangkaian langkah-langkah yang dilakukan secara terencana dan sistematis guna mendapatkan pemecahan masalah atau mendapatkan jawaban terhadap pertanyaan-pertanyaan tertentu. (J. Supranto, 2003) Sedangkan pengertian metodologi dalam pelaksanaan suatu penelitian adalah persoalan pokok yang cukup menentukan, metodologi merupakan suatu unsur yang mutlak harus ada di dalam penelitian dan pengembangan ilmu pengetahuan.( Cipta Soerjono Soekanto, 1986)

Penelitian ini adalah suatu penelitian yang bersifat deskriptif, yaitu suatu penelitian yang mengambarkan tentang penangan penyidik dalam tidak pidana pencabulan. Metode Pendekatan masalah yang dipergunakan dalam penelitian ini adalah penelitian secara yuridis normatif. Menurut Soerjono Soekanto pendekatan yuridis normatif yaitu penelitian hukum yang dilakukan dengan cara meneliti bahan pustaka atau data sekunder sebagai bahan dasar untuk diteliti dengan cara mengadakan penelusuran terhadap peraturan-peraturan dan literatur-literatur yang berkaitan dengan permasalahan yang diteliti. (Soerjono Soekanto \& Sri Mamudji, 2001)

\section{HASIL DAN PEMBAHASAN}

\section{Pelaksanaan Penanganan Penyidikan Tindak Pidana Persetubuhan Dan Pencabulan Terhadap Anak Di Polsek Empat Angkat Candung}

Berdasarkan hasil wawancara dengan Ipda Erman Penyidik Polsek Empat Angkat Candung. Pelaksanaan Penyidikan sudah sesuai dengan Peraturan 
Rahmat Fauzi: Pelaksanaan Penanganan Penyidikan Tindak Pidana Persetubuhan...

perundang-undangan. Pelaksanaan penyidikan yang dilakukan oleh penyidik terhadap tersangka pelaku tindak pidana yang berkaitan dengan persetubuhan dan pencabulan adalah sebagai berikut:

a. Melakukan pemeriksaan terhadap korban tindak pidana yang berkaitan dengan persetubuhan dan pencabulan.

Pemeriksaan yang dilakukan oleh penyidik Polsek Empat Angkat Candung terhadap korban tindak pidana persetubuhan dan pencabulan mempunyai tujuan untuk mendapatkan keterangan atas tindak pidana yang telah menimpa korban yang akan membantu penyidik di dalam proses pemeriksaan terhadap pelaku tindak pidana.

b. Pemeriksaan saksi-saksi untuk di dengar keterangannya

Pemeriksaan saksi bertujuan untuk memberikan keterangan dalam rangka penyidikan suatu perkara tindak pidana yang ia dengar sendiri, ia dengar sendiri dan ia lihat sendiri. Keterangan saksi akan di muat dalam Berita Acara Pemeriksaan (BAP) sebagai bukti bahwa telah memberikan keterangan dalam tindak pidana yang berkaitan dengan persetubuhan dan pencabulan.

Tata cara pemeriksaan saksi oleh penyidik Polsek Empat Angkat Candung yang berkaitan dengan tindak pidana yang berkaitan dengan persetubuhan dan pencabulan adalah:
1) Saksi diperiksa sendiri, tetapi dalam hal tertentu dapat dipertemukan satu dengan yang lainnya.

2) Saksi diperiksa tanpa tekanan dari siapapun dan dalam bentuk apapun dan saksi berkewajiban untuk memberikan keterangan dengan sebenar-benarnya.

3) Keterangan saksi dicatat di dalam Berita Acara Pemeriksaan (BAP) yang di tanda tangani oleh penyidik setelah saksi menyetujui isinya. Apabila saksi tidak setuju untuk menandatangani maka penyidik akan mencatatnya di dalam berita acara pemeriksaan serta dengan menyebutkan alasan kenapa saksi tidak mau menandatangani.

Jika penyidik memerlukan adanya keterangan seorang saksi ahli untuk dimintai keterangan maka ia dapat meminta pendapat dari seorang ahli yang mempunyai keahlian khusus.

c. Melakukan pemeriksaan terhadap pelaku tindak pidana yang berkaitan dengan persetubuhan dan pencabulan.

Tujuan dari pemeriksaan terhadap pemeriksaan pelaku tindak pidana yang berkaitan dengan persetubuhan dan pencabulan untuk memastikan benar atau tidaknya perbuatan yang dilakukan tersangka, jika dari hasil pemeriksaan bahwa perbuatan yang telah dilakukan tersangka memiliki unsur-unsur tindak pidana, maka sejak diterima laporan tersebut dapat dilakukan pemeriksaan sesuai dengan hukum acara pidana. 
Kemudian penyidik akan mencatat keterangan yang di berikan oleh pelaku tindak pidana yang berkaitan dengan persetubuhan dan pencabulan ke dalam Berita Acara Pemeriksaan (BAP) dengan serincirincinya, sesuai dengan apa yang telah dikatakan oleh tersangka.

\section{d. Pembuatan Berita Acara Penyidikan}

Setelah proses pemeriksaan pelaku tindak pidana yang berkaitan dengan penganiayaan di rasa telah cukup, maka penyidik akan membuat Berita Acara Pemeriksaan. Dalam Berita Acara Pemeriksaan berisi tentang keterangan tersangka pelaku tindak pidana yang berkaitan dengan persetubuhan dan pencabulan, berita acara penggeledahan, berita acara penyitaan dan seterusnya.

e. Penggeledahan

Penggeledahan dilakukan untuk mendapatkan barang bukti yang berkaitan dengan tindak pidana persetubuhan dan pencabulan. Dalam melakukan penggeledahan penyidik harus mempunyai surat izin dari ketua pengadilan. Sebelum melakukan penggeledahan penyidik terlebih dahulu harus menunjukkan tanda pengenal ke pihak tersangka atau keluarganya. Guna keamanan dan ketertiban dalam penggeledahan, petugas dapat melakukan penjagaan tempat yang bersangkutan dan berhak memerintahkan orang untuk tidak meninggalkan temapat tersebut. Apabila tempat yang akan digeledah berada di luar wilayah hukum Polsek Empat Angkat Candung maka penggeledahan harus didampingi oleh penyidik setempat.

f. Penyitaan barang bukti yang digunakan untuk melakukan tindak pidana

Di dalam melakukan penyitaan ada ketentuan-ketentuan yang harus di jalankan oleh penyidik antara lain harus mempunyai surat izin untuk melakukan penyitaan, menunjukkan tanda pengenal, penyidik memerintahkan kepada tersangka untuk menyerahkan barang bukti yang telah ia gunakan untuk melakukan tindak pidana yang berkaitan dengan persetubuhan dan pencabulan, dan penyidik akan membungkus barang bukti yang disita.

g. Penyerahan berkas perkara ke pengadilan untuk menjalani sidang

Jika di dalam proses pemeriksaan tindak pidana yang berkaitan dengan persetubuhan dan pencabulan sudah selesai maka berkas akan di serahkan ke pada pengadilan. Namun jika berkas di nilai kurang lengkap maka pihak pengadilan akan mengembalikan berkas tersebut kepada penyidik untuk melengkapinya dan penyidik berkewajiban untuk melakukan penyidikan tambahan guna melengkapi berkas yang akan dilimpahkan ke pengadilan.

Pelaksanaan proses penyidikan terhadap tindak pidana yang berkaitan dengan persetubuhan dan pencabulan yang diperiksa di Polsek Empat Angkat Candung telah dilakukan berdasarkan hukum yang berlaku di Indonesia, hal ini 
Rahmat Fauzi: Pelaksanaan Penanganan Penyidikan Tindak Pidana Persetubuhan...

terlihat dari telah dilakukannya prosedur-prosedur tindakan penyidik dalam melakukan proses penyidikan. Dan proses penyidikan ini berdasarkan ketentuan Pasal 351 KUHP Tentang Penganiayaan.

\section{Faktor Penghambat Penyidik Dalam Memproses Perkara Tindak Pidana Persetubuhan Dan Pencabulan Terhadap Anak Di Polsek Empat Angkat Candung}

Dalam melakukan penyidikan tindak pidana persetubuhan dan pencabulan terhadap anak penyidik menemui hambatan-hambatan atau kendala yang dihadapi. Hal ini berdasarkan wawancara dengan Penyidik dan Penyidik Pembantu di Polsek Empat Angkat Candung.

a. Hambatan yang menyangkut segi sumber daya manusia dari penyidik

Hal ini merupakan hambatan yang paling penting dan yang paling utama dari penyidik yang kurang memahami materi pasal 290 KUHP maupun pengalaman penanganan terhadap kasus tersebut yang sangat berpengaruh atas keberhasilan dalam penanganan penyidikan kasus tersebut. Kendala yang menyangkut kurangnya pengetahuan penyidik memahami materi pasal 290 KUHP sempat menjadi kekhawatiran Polsek Empat Angkat Candung. Di Polesk Empat Angkat Candung hanya memilik 3 orang penyidik, sedangkan yang seharusnya adalah 7 orang penyidik itupun belum ada yang serjana. Suatu misal pelaku kasus pelanggaran 290 KUHP yang dilakukan oleh orang yang mempunyai pendidikan tinggi dan tahu celah-celah hukum, padahal tenaga penyidik kurang memahami materi dari pasal tersebut yang kemudian akan menyulitkan dalam penanganan penyidikan kasus tindak pidana pencabulan itu. Karena adanya pemikiran tersebut Poles Polsek Empat Angkat Candung, selalu menekankan kepada anggotanya untuk memahami materi pasal-pasal dalam KUHP sebelum melakukan penyelidikan atau penyidikan.

b. Korban masih anak-anak

Perkara tindak pidana persetubuhan dan pencabulan yang terjadi di Polsek Empat Angkat Candung korbanya adalah anak yang masih berumur 5 tahun. Ini merupakan kesulitan bagi penyidik dalam meminta keteragan, karena keterangan yang diberikan berbelit-belit.

c. Tersangka tidak mengaku

Tersangka tindak pidana persetubuhan dan pencabulan yang terjadi di Polsek Empat Angkat Candung tidak mengakui bahwa dia yang melakukan persetubuhan terhadap ZI yang menjadi korban. Hal ini membutuhkan kerja keras penyidik untuk mengumpulakan buktibukti tentang perkara ini.

d. Tidak ada nya saksi yang melihat secara langsung dan saksi tidak mau datang untuk memberikan keterangan

Dalam menyelesaikan perkara membutuhkan saksi untuk mendapatkan keterangan yang untuk mengungkap suatu perkara. Kasus yang terjadi di Polsek Empat Angkat Candung ini tidak ada yang melihat secara langsung kejadiaan pencabulan dan persetubuhan terhadap 
anak ini. Saksi yang ditujuk yaitu masyarakat kurang mengetahui hukum. Jadi tidak mau mendatangi polsek utnuk memberikan keterangan.

e. Kerbatansan Dokter Forensik

Dokter Forensik sangatlah berperan penting untuk mengetahui hasil Visum, namun di Koto Bukittinggi dan Kabupaten Agam hanya memiliki satu dokter forensik yang hanya datang hari senin sampai jumat (tidak teratur datangnya). Jika kejadian hari sabtu maka penyidik harus menunggu hari senin untuk visum korban pencabulan dan persetubuhan, hasilnya juga keluar seminggu setelah visum.

\section{Jalan Keluar Yang Diambil} Penyidik Dalam Memproses Perkara Tindak Pidana Persetubuhan Dan Pencabulan Terhadap Anak Di Polsek Empat Angkat Candung

Berdasarkan wawancara dengan Penyidik dan Penyidik Pembantu di Polsek Empat Angkat Candung tentang tindak pidana persetubuhan dan pencabulan terhadap anak ini. jalan keluar yang diambil penyidik dalam memproses perkara ini adalah:

a. Mengatasi hambatan yang menyangkut segi sumber daya manusia dari penyidik di Polsek Empat Angkat Candung. Kapolsek Empat Angkat Candung berusaha untuk mengoptimalkan penyidik yang ada, di samping itu kapolsek mengajukan penambahan angota penyidik ke Polres. b. Mengatasi permasalahan korban masih anak-anak, penyidik di Polsek Empat Angkat Candung mengalukan dan meminta bantuan untuk mendamping korban pencabulan dan persetubuan ini ke Dinas Sosial Bukittinggi.

c. Tidak ada nya saksi yang melihat secara langsung ini diatasi dengan memperbanyak saksi yang akan memberikan keterangan tentang kasus pencabulan dan persetubuhan terhadap anak di Empat Angkat Candung ini. Sedang untuk saksi tidak mau datang untuk memberikan keterangan ke penyidik, maka akan dilakukang pemanggilan ulang. Jika masih tidak mau datang, maka akan didatangi kerumah agar bisa memberikan keterangan.

d. Tersangka tidak mengaku menjadi kendala yang sangat berat bagi penyidik. Untuk mengungkap perkara ini, maka penyidik melakukan gelar perkara di lokasi, memproses barang bukti dan memperbanyak menghadirkan saksi untuk memberikan keterangan.

e. Dokter Forensik sangatlah berperan penting untuk mengetahui hasil Visum. Jadi penyidik Polsek Empat Angkat Candung tetap menunggu hasil dari dokter Forensik ini. Karena hanya satu-satunya yang berada di kota Bukittinggi dan Kabupaten Agam. Hal ini dilakukan karena sangat di butukan hasil Visumnya, sebab tersangka tidak mengakui perbuatannya. 
Rahmat Fauzi: Pelaksanaan Penanganan Penyidikan Tindak Pidana Persetubuhan...

\section{SIMPULAN}

Berdasarkan hasil penelitian dan pembahasan tentang Pelaksanaan Penanganan Perkara Pidana oleh Penyidik dalam Tindak Pidana Persetubuhan dan Perbuatan Cabul terhadap Anak (Studi Kasus

Nomor:

LP/35/IV/2016/Sek.IV.AC)" yang telah diuraikan di atas, maka dapat ditarik kesimpulan sebagai berikut:

1. Penangan penyidikan tindak pidana persetubuhan dan pencabulan terhadap anak yang dilakukan oleh aparat penyidik Polsek Empat Angkat Candung telah sesuai dengan ketentuan peraturan perundangundangan. Namun terdapat hambatanhambatan yang harus diselesaikan dan dicarikan jalan keluarnya. Penyidikan terhadap kasus ini sesuai dengan aturan yang ada yaitu menerima laporan, melakukan sita barang bukti, penangkapan, penahanan pemberkasan dan kirim berkas ke Jaksa Penuntut Umum (P21). Menurut hemat peneliti semua tahapan penyidikan tersebut telah sesuai dengan ketentuan KUHAP.

2. Faktor penghambat penyidik dalam memproses perkara tindak pidana persetubuhan dan pencabulan Terhadap Anak yaitu: hambatan yang menyangkut segi sumber daya manusia dari penyidik, korban masih anak-anak, tersangka tidak mengaku, tidak ada nya saksi yang melihat secara langsung dan saksi tidak mau datang untuk memberikan keterangan dan keterbatansan dokter forensik.
3. Jalan keluar yang diambil penyidik dalam memproses perkara tindak pidana persetubuhan dan pencabulan terhadap anak adalah berusaha untuk mengoptimalkan penyidik yang ada dan mengajukan penambahan anggota penyidik ke Polres, mengalukan dan meminta bantuan untuk mendampingi korban pencabulan dan persetubuhan ini ke Dinas Sosial bukittinggi, memperbanyak saksi untuk memberikan keterangan dan saksi tidak mau datang maka dilakukan pemanggilan ulang setelah itu didatangi ke rumah agar bisa memberikan keterangan, tersangka tidak mengaku maka penyidik melakukan gelar perkara di lokasi, memproses barang bukti dan memperbanyak menghadirkan saksi untuk memberikan keterangan dan keterbatasan Dokter Forensik, maka penyidik tetap menunggu hasil visum.

\section{DAFTAR PUSTAKA}

Agil Widiyas Sampurna, S. (2016). Penyidikan Terhadap Anak Sebagai Pelaku Tindak Pidana Pelecehan Seksual Oleh Penyidik Unit Ppa Satuan Reskrim Berbasis Keadilan Restoratif Di Kabupaten Kendal, 12 (1), 145-167.

Aprilianda, N. (2017). Perlindungan anak korban kekerasan seksual melalui pendekatan keadilan restoratif. Arena hukum, 10 (2), 309-332.

Bob Sadiwijaya, Marlina, Mahmud Mulyadi, U. M. B. (2013). Penegakan Hukum Pidana Dalam Tindak Pidana Pencabulan Terhadap Anak (Studi Putusan No. 
Jurnal Cendekia Hukum: Vol. 5, No 1, September 2019

396/PID.B/2012/PN-LP Di

Pengadilan Negeri Lubuk Pakam). USU Law Journal, 1 (1), 1-18.

Cipta Soerjono Soekanto,1986, Pengantar

Penelitian Hukum, Universitas Indonesia (UI-Press), Jakarta.

Fachri Bey, F. I. (2011). Proses Pembuktian Tindak Pidana Pencabulan Terhadap. Lex Jurnalica, 8 (3), 225-252.

Gadis Arivia, 2005, Potret Buram Eksploitasi Kekerasan Seksual pada Anak Ford Foundation, Universitas Terbuka, Jakarta.

J. Supranto, 2003, Metode Penelitian Hukum dan Statistik, Rineka, Jakarta.

Kartini Kartono, 1983, Patologi Sosial, CV. Rajawali, Jakarta.

Kartini Kartono, 1985, Psikologi Abnormal dan Abnormalitas Seksual, Mandar Maju, Bandung.
Moeljatno, 1993, Asas-Asas Hukum Pidana, Rineka Cipta, Jakarta.

Soerjono Soekanto \& Sri Mamudji, 2001, Penelitian Hukum Normatif (Suatu Tinjauan Singkat), Rajawali Pers, Jakarta.

Putra, Y. M., Sabardi, L., \& Parman, L. (2018). Perlindungan Hukum Terhadap Anak Pelaku Tindak Pidana Persetubuhan Dalam Sistem Peradilan Pidana Anak (Kajian Atas Putusan Pengadilan Negeri Selong Nomor 04/PID.SUS.ANAK/2015/PN.SEL). Jurnal IUS, 6 (2), 294-306.

Wahyuningsih, S. E. (2016). Perlindungan Hukum Terhadap Anak Sebagai Korban Tindak Pidana Kesusilaan Dalam Hukum Pidana Positif Saat Ini. Jurnal Pembaharuan Hukum, III (2), 172-180. 